\title{
Carbon Sequestration by Glomeral Fungi in Soil is Influenced by Phosphorus and Nitrogen Fertilization
}

\author{
N. Aliasgharzad ${ }^{\# 1}$, Z. Afshari ${ }^{\# 2}$ and N. Najafi ${ }^{\# 3}$ \\ \# Department of Soil Science, University of Tabriz, Tabriz, 51664-16471, Iran \\ E-mail: ${ }^{1}$ n-aliasghar@tabrizu.ac.ir, ${ }^{2}$ zafshari1390@yahoo.com, ${ }^{3}$ n-najafi@tabrizu.ac.ir
}

\begin{abstract}
Glomalin is the most abundant gylcoprotein in soil which produces by glomeral fungi in symbiosis with plant roots. It improves soil physical, chemical and biological properties. Assimilated plant $\mathbf{C}$ which is allocated to the mycorrhizal fungus, appears as a recalcitrant glycoprotein (glomalin) in cell walls of hyphae and spores. Considering global warming due to increasing greenhouse gases, this phenomenon could be important in carbon sequestration and reducing $\mathrm{CO}_{2}$ in atmosphere. Chemical fertilizers could affect symbiotic relations of these fungi, which in turn affect glomalin production. In a pot culture experiment, the sterile soil was treated with $0,100,200 \mathrm{mg} \mathrm{N} \mathrm{kg}{ }^{-1}$ soil as urea or $0,20,40 \mathrm{mg} \mathrm{kg}^{-1}$ soil as triple superphosphate, in two separate factorial experiment based on completely randomized design with three replications. Corn plant (Zea mays L.) was inoculated with Rhizophagus clarus (formerly, Glomus clarum) or Rhizophagus intraradices (formerly, Glomus intraradices) in each set of experiment. Easley extractable glomalin (EEG) and total glomalin (TG) in soil were determined by Bradford method at the end of experiment. Root colonization by both fungi increased EEG and TG compared to the non-mycorrhizal control $(p<0.05)$. Nitrogen levels of 100,200 increased EEG by 75 and $112 \%$ and TG by 59 and $76 \%$, respectively, compared to the no nitrogen treatment. P levels of 20,40 caused $27 \%$ increase and $6 \%$ decrease in EEG, and $24 \%$ increase and $13 \%$ decrease in TG, respectively, compared to the zero addition of phosphorus. Regarding glomalin production in this condition, $R$. clarus was more efficient than $R$. intraradices. Application of 20 mg $\mathrm{P} \mathrm{kg}^{-1}$ increased root colonization, dry weights of shoot and root, chlorophyll index, leaf area, amount of shoot and root nitrogen and potassium compared to the $40 \mathrm{mgP}$. $\mathrm{kg}^{-1}$ and control. Thus, application of $100 \mathrm{mg} \mathrm{N} \mathrm{kg}$ increased root colonization, dry weights of shoot and root, chlorophyll index, leaf area, amount of shoot and root phosphorus and potassium compared to the $200 \mathrm{mg}^{\mathrm{N}} \mathrm{kg}^{-1}$ and control.
\end{abstract}

Keywords - Glomalin; Mycorrhizal fungi; Corn; Chemical fertilizers; Soil carbon

\section{INTRODUCTION}

Over the past 150 years, the amount of carbon in the atmosphere has increased by $30 \%$. Most scientists believe there is a direct relationship between increased levels of carbon dioxide in the atmosphere and rising global temperatures. One proposed method to reduce atmospheric carbon dioxide is to increase the global storage of carbon in soils. Soil carbon storage is an important function of terrestrial ecosystems.

It is recently coming to light that mycorrhizal fungi may play an important role in maintaining this pool in soil [1],[2],[18]. Measurements of plant carbon allocation to mycorrhizal fungi have been estimated to be $5-20 \%$ of total plant carbon uptake [1] and in some ecosystems the biomass of mycorrhizal fungi can be comparable to the biomass of fine roots. Recent research has shown that mycorrhizal fungi hold 50 to 70 percent of the total carbon stored in leaf litter and soils of forest lands [8],[13]. Based on the magnitude of mycorrhizal fungal inputs to the soil carbon pool, some have suggested that variation in the recalcitrance of mycorrhizal biomass may be important for predicting soil carbon storage, as it would affect the rate at which the contribution of mycorrhizal fungi to soil carbon is returned to the atmosphere [3],[5],[8].

The glomalin, a glycoprotein produced only by arbuscular mycorrhizal fungi, has been found to accumulate in some soils, and may be a substantial fraction of the soil carbon pool in these ecosystems [6],[16]. It may be hiding place for up to $\% 30$ of soil organic carbon. Glomalin as a recalcitrant glycoprotein with half life of about 50 years, persist in soil for a long time. By this way, the key role of glomalin in carbon sequestration in terrestrial ecosystems is well obvious [4], [17].

Glomalin is synthesized by the fungi and accumulates in cell wall of spore and hyphae [17]. There are evidences that glomalin protect fungi from environmental stresses (temperature, moisture, salinity, heavy metals, etc). It also protects hyphae during transport of nutrients from the plant to the hyphal tip and from soil to the plant. Amino acid 
sequencing of glomalin indicates that it has similarity with heat shock proteins (HSPs) [7]. It releases to the soil after fungal dead, therefore, it accumulates in soils in considerable amounts annually. The growth of arbuscular mycorrhizal fungi completely depends on its host plant status. Any change in host plant growth conditions, will reflect on fungal development and consequently on glomalin production [12]. $\mathrm{Wu}$ et al. [24] pointed out that the application of nitrogen and phosphorus fertilizers at low level could induce arbuscular mycorrhizal development and consequently enhance glomalin production. Others reported no significant effect of nitrogen on glomalin production [22]. Unlike to the nitrogen, the higher level of phosphorus may inhibits glomalin production by reducing AM fungal development in host roots.

This study was aimed to evaluate the effects of $\mathrm{N}$ and $\mathrm{P}$ fertilizers on AMF development and glomalin production. We hypothesized that supplying nitrogen would enhance but phosphorus (specially at higher levels) would diminish glomalin production by the fungi.

\section{MATERIALS AND METHODS}

\section{A. Fungal Species}

Rhizophagus clarus (formerly, Glomus clarum) and Rhizophagus intraradices (formerly, Glomus intraradices) were obtained from Biology Department of Lund University, Sweden. The fungal species were propagated with maize plants in 4-L pots containing sterile sandy loam soil. Rorison's nutrient solution prepared with deionized water with $1 / 2$ strength of phosphorus was added to the pots twice a week to bring the soil moisture to field capacity [15]. Pots were kept in greenhouse with $28 / 20{ }^{\circ} \mathrm{C}$ day/night and $16 / 8 \mathrm{~h}$ light/dark period. After 4 months, top plants were cut off and pot materials containing soil, mycorrhizal roots, hyphae and spores were thoroughly mixed and used as fungal inoculum.

\section{B. Plant Material and Fungal Inoculation}

Seeds of corn plant (Zea mays L. Single Cross 704) were surface sterilized with $\% 1$ sodium hypochlorite and sown in pots containing $2 \mathrm{~kg}$ sterile soil. A loamy sand soil with $\mathrm{pH}$ 7.8, ECe $1.4 \mathrm{dSm}^{-1}$, organic carbon $0.22 \%, \mathrm{~K}_{\text {ava. }} 182.6 \mathrm{mgkg}^{-}$ ${ }^{1}$ and $\mathrm{P}_{\text {ava. }} 4.4 \mathrm{mgkg}^{-1}$ was used in this study. The sterile soil was treated with $0,100,200 \mathrm{mg} \mathrm{N} \mathrm{kg}^{-1}$ soil as urea or 0,20 , $40 \mathrm{mg} \mathrm{P} \mathrm{kg}^{-1}$ soil as triple superphosphate, in two separate factorial experiment based on completely randomized design with three replications. All pots received $\mathrm{K}$ fertilizer as $\mathrm{K}_{2} \mathrm{SO}_{4}$ at a rate of $80 \mathrm{mg} \mathrm{K} / \mathrm{kg}$ soil.

Fungal inoculants at a rate of $80 \mathrm{~g} /$ pot was spread at depth of $5 \mathrm{~cm}$ below the soil surface as a thin layer, in each set of experiment.

\section{Chlorophyll Index, Plant N, P and Dry Weight}

Eighty days after sowing, the chlorophyll index was measured using Spad Hanstech Cl-01, then plants were harvested and shoot and root dry weights were determined after drying at $60{ }^{\circ} \mathrm{C}$ for $48 \mathrm{~h}$. Nitrogen and phosphorus concentrations in shoot and root were measured according to the standard methods.

\section{Root Colonization}

Fine roots were cleaned in $\% 10 \mathrm{KOH}$ followed by staining with lacto-glycerol trypan blue [23]. Root colonization percentage was determined as per described by Giovannetti and Mosse [25].

\section{E. Glomalin Determination}

Easley extractable glomalin (EEG) and total glomalin (TG) in soil were extracted with 20 and $50 \mathrm{mM}$ citrate buffer, respectively [14]. Briefly, one gram of soil $(<2 \mathrm{~mm})$ was mixed with $8 \mathrm{~mL}$ of $20 \mathrm{mM}$ citrate buffer, $\mathrm{pH} 7$ for EEG or $50 \mathrm{mM}$ citrate buffer, $\mathrm{pH} 8$ for TG in a test tube and autoclaved at $121{ }^{\circ} \mathrm{C}$ for $30 \mathrm{~min}$. It was then centrifuged at $5000 \mathrm{RPM}$ for $15 \mathrm{~min}$. The supernatant was assayed for glomalin concentration using Bradford method [26]. Bovine serum albumin (BSA) was used for preparation calibration standard curve.

\section{RESULTS AND DISCUSSION}

\section{A. Plant Dry Weights and N, P Concentrations}

Root and shoot dry matter were significantly increased by $\mathrm{N}$ fertilization up to $100 \mathrm{mg} / \mathrm{kg}$ but the higher level of nitrogen (N200) had adverse effect on both criteria. In each level of nitrogen, mycorrhizal plants had higher shoot and root biomass than non-mycorrhizal ones, although the Rc was efficient than Ri fungus. The highest shoot and root dry weights were achieved in Rc inoculated plants with N100 level. Nitrogen concentration in shoot and root was enhanced by rising of N level to N200.

TABLE I

EFFECTS OF N FERTILIZATION AND FUNGAL INOCULATION ON PLANT BIOMASS AND NUTRIENTS CONCENTRATIONS.

\begin{tabular}{|c|c|c|c|c|c|c|c|c|}
\hline \multirow{2}{*}{\multicolumn{2}{|c|}{ Treatments }} & \multirow{3}{*}{$\begin{array}{c}\begin{array}{c}\text { Shoot DW } \\
\text { g pot }^{-1}\end{array} \\
4.34 \mathrm{f} \\
\end{array}$} & \multirow{3}{*}{$\begin{array}{c}\begin{array}{c}\text { Root DW } \\
\text { g pot }^{-1}\end{array} \\
1.95 \mathrm{~h} \\
\end{array}$} & \multirow{3}{*}{$\begin{array}{c}\text { CI } \\
1.59 \mathrm{~g} \\
\end{array}$} & \multicolumn{2}{|c|}{ Shoot } & \multicolumn{2}{|c|}{ Root } \\
\hline & & & & & \multirow{2}{*}{$\begin{array}{c}\% \mathrm{~N} \\
0.30 \mathrm{~h}\end{array}$} & \multirow{2}{*}{$\begin{array}{c}\% \mathrm{P} \\
0.30 \mathrm{c} \\
\end{array}$} & \multirow{2}{*}{$\begin{array}{c}\% \mathrm{~N} \\
0.35 \mathrm{~g} \\
\end{array}$} & \multirow{2}{*}{$\begin{array}{c}\% \mathrm{P} \\
0.36 \mathrm{~b} \\
\end{array}$} \\
\hline \multirow{3}{*}{ NO } & NM & & & & & & & \\
\hline & $\mathrm{Rc}$ & $6.10 \mathrm{e}$ & $3.21 \mathrm{~g}$ & $2.21 \mathrm{f}$ & $0.34 \mathrm{~g}$ & $0.33 b$ & $0.44 \mathrm{e}$ & $0.43 \mathrm{a}$ \\
\hline & $\mathrm{Ri}$ & $6.44 \mathrm{e}$ & $4.16 f$ & $2.41 \mathrm{e}$ & $0.34 \mathrm{~g}$ & $0.33 \mathrm{~b}$ & $0.40 \mathrm{f}$ & $0.44 \mathrm{a}$ \\
\hline \multirow{3}{*}{ N100 } & NM & $14.22 \mathrm{c}$ & $4.93 \mathrm{e}$ & $6.54 \mathrm{~d}$ & $0.80 \mathrm{f}$ & $0.18 \mathrm{~g}$ & $0.65 \mathrm{~d}$ & $0.38 \mathrm{~d}$ \\
\hline & $\mathrm{Rc}$ & $19.94 \mathrm{a}$ & $10.94 \mathrm{a}$ & $7.29 \mathrm{c}$ & $0.95 \mathrm{~d}$ & $0.20 \mathrm{e}$ & $0.67 \mathrm{~d}$ & $0.31 \mathrm{c}$ \\
\hline & $\mathrm{Ri}$ & $17.61 \mathrm{~b}$ & $9.27 \mathrm{~b}$ & $7.13 \mathrm{c}$ & $0.88 \mathrm{e}$ & $0.19 \mathrm{f}$ & $0.67 \mathrm{~d}$ & $0.30 \mathrm{c}$ \\
\hline \multirow{3}{*}{ N200 } & NM & $10.11 \mathrm{~d}$ & $3.65 \mathrm{fg}$ & $11.07 \mathrm{a}$ & $1.53 \mathrm{a}$ & $0.20 \mathrm{e}$ & $1.48 \mathrm{a}$ & $0.24 \mathrm{e}$ \\
\hline & $\mathrm{Rc}$ & $17.33 \mathrm{~b}$ & $8.07 \mathrm{c}$ & $11.06 \mathrm{a}$ & $1.38 \mathrm{~b}$ & $0.21 \mathrm{~d}$ & $1.20 \mathrm{~b}$ & $0.27 \mathrm{~d}$ \\
\hline & $\mathrm{Ri}$ & $14.76 \mathrm{c}$ & $6.85 \mathrm{~d}$ & $10.43 b$ & $1.28 \mathrm{c}$ & $0.20 \mathrm{e}$ & $1.14 \mathrm{c}$ & $0.28 \mathrm{~d}$ \\
\hline
\end{tabular}

Means in each column followed by same letter are not significantly different at $p<0.05$.

DW: dry weight, CI: chlorophyll index, NM: non-mycorrhizal, Rc: Rhizophagus clarus, Ri:Rhizophagus intraradices. 
Higher N uptake by plant in N200 level did not cause any increase in shoot and root biomass but prevented them to a marked extent. The positive effect of both fungi on $\mathrm{N}$ uptake was seen in N0 and N100 levels. Phosphorus concentration of shoot and root was negatively affected by increasing of $n$ level, likely due to dilution effect. In each level of $\mathrm{N}$ fertilizer, mycorrhizal inoculation lead to marked increase in shoot and root $\mathrm{P}$ compared to the non-mycorrizal plants. Increment of chlorophyll index was obtained by both $\mathrm{N}$ fertilization and fungal inoculation, although the positive effect of fungi was distinct in N0 and N100 levels (Table.1).

The effects of phosphorus fertilization on shoot and root growth and $\mathrm{N}$ and $\mathrm{P}$ uptake had same trend as nitrogen, but the phosphorus level of P40 had more preventing effect on shoot and root biomass production.

Symbiotic efficiency of both fungi on shoot and root growth and $\mathrm{P}$ allocation to the plant was considerable at $\mathrm{P} 0$ level and to the some extent at P20 level, but they were not efficient in P40 level (Table.2). There are evidences that higher availability of $\mathrm{P}$ in soil inhibits the development of mycorrhizal symbiosis which lead to decrease in beneficial effect of fungi [9], [11]. Chlorophyll index was significantly increased in mycorrhizal plants compared to the nonmycorrhizal ones at P0 and P20 levels. There was no positive effect of fungal inoculation on chlorophyll index at
P40 level (Table 2). It seems that at higher P level, the fungi could not exert beneficial effect on chlorophyll synthesis.

\section{B. SoilEEG}

Soil EEG was significantly increased by increasing nitrogen level in both fungal inoculations. The enhancement of EEG in the presence of Rc fungus was more than $\mathrm{Ri}$ $(p<0.05)$. The increase was also seen in non-mycorrhizal treatment (Fig.1). Glomalin synthesis by the fungi is positively affected by nitrogen availability in soil. Nitrogen is the main constituent of this glycoprotein.

The results indicate that glomalin as a recalcitrant carbon source can accumulate in soil by $\mathrm{N}$ fertilization. Plant photosynthates are translocated to the fungal organs via roots and mainly utilize for glomalin synthesis in hyphal and spore cell walls. During this process, nitrogen plays an important role as constituent of the glycoprotein [22]. The Bradford method [26] was used for glomalin determination in this study. The method is not specific for glomalin and therefore measures other glomalin related proteins and glycoproteins as well [17]. By this way, other proteins which increase by $\mathrm{N}$ fertilization, come to account in Bradford assessment. This might be a reason for increase of EEG by rising $\mathrm{N}$ level in non-mycorrhizal treatment.

TABLE II

EFFECTS OF P FERTILIZATION AND FUNGAL INOCULATION ON PLANT BIOMASS AND NUTRIENTS CONCENTRATIONS.

\begin{tabular}{|c|c|c|c|c|c|c|c|c|}
\hline \multirow{2}{*}{\multicolumn{2}{|c|}{ Treatments }} & \multirow{3}{*}{$\begin{array}{c}\begin{array}{c}\text { Shoot DW } \\
\text { g pot }^{-1}\end{array} \\
377 \mathrm{~g}\end{array}$} & \multirow{3}{*}{$\begin{array}{c}\begin{array}{c}\text { Root DW } \\
\text { g pot }^{-1}\end{array} \\
2.39 \mathrm{e}\end{array}$} & \multirow{3}{*}{$\frac{\mathrm{CI}}{6.68 \mathrm{~d}}$} & \multicolumn{2}{|c|}{ Shoot } & \multicolumn{2}{|c|}{ Root } \\
\hline & & & & & $\% \mathrm{~N}$ & $\% \mathrm{P}$ & $\% \mathrm{~N}$ & $\% \mathrm{P}$ \\
\hline \multirow{3}{*}{ P0 } & NM & & & & $0.99 \mathrm{a}$ & $0.18 \mathrm{e}$ & $0.96 \mathrm{a}$ & $0.23 \mathrm{e}$ \\
\hline & $\mathrm{Rc}$ & $9.11 \mathrm{e}$ & $5.47 \mathrm{bc}$ & $8.65 a$ & $0.85 \mathrm{c}$ & $0.21 \mathrm{~d}$ & $0.81 \mathrm{~b}$ & $0.26 \mathrm{c}$ \\
\hline & $\mathrm{Ri}$ & $7.85 \mathrm{f}$ & $4.66 \mathrm{~d}$ & $8.28 \mathrm{~b}$ & $0.89 \mathrm{~b}$ & $0.21 \mathrm{~d}$ & $0.75 \mathrm{c}$ & $0.24 \mathrm{~d}$ \\
\hline \multirow{3}{*}{ P20 } & NM & $14.80 \mathrm{~b}$ & $5.89 \mathrm{~b}$ & $5.40 \mathrm{~g}$ & $0.67 \mathrm{f}$ & $0.22 \mathrm{c}$ & $0.54 \mathrm{f}$ & $0.32 \mathrm{a}$ \\
\hline & $\mathrm{Rc}$ & $19.48 \mathrm{a}$ & $8.99 \mathrm{a}$ & $6.43 \mathrm{e}$ & $0.84 \mathrm{c}$ & $0.24 \mathrm{~b}$ & $0.63 \mathrm{de}$ & $0.32 \mathrm{a}$ \\
\hline & $\mathrm{Ri}$ & $18.60 \mathrm{a}$ & $8.32 \mathrm{a}$ & $6.17 \mathrm{f}$ & $0.79 \mathrm{~d}$ & $0.23 b c$ & $0.57 \mathrm{ef}$ & $0.30 \mathrm{~b}$ \\
\hline \multirow{3}{*}{$\mathrm{P} 40$} & NM & $12.53 \mathrm{c}$ & $5.71 \mathrm{~b}$ & $7.39 \mathrm{c}$ & $0.72 \mathrm{ef}$ & $0.27 \mathrm{a}$ & $0.55 \mathrm{f}$ & $0.29 \mathrm{~b}$ \\
\hline & $\mathrm{Rc}$ & $12.62 \mathrm{c}$ & $5.15 \mathrm{bcd}$ & $7.47 \mathrm{c}$ & $0.77 \mathrm{de}$ & $0.28 \mathrm{a}$ & $0.58 \mathrm{def}$ & $0.30 \mathrm{~b}$ \\
\hline & $\mathrm{Ri}$ & $11.49 \mathrm{~d}$ & $4.74 \mathrm{~cd}$ & $7.50 \mathrm{c}$ & $0.74 \mathrm{e}$ & $0.27 \mathrm{a}$ & $0.64 \mathrm{~d}$ & $0.30 \mathrm{~b}$ \\
\hline
\end{tabular}

Means in each column followed by same letter are not significantly different at $p<0.05$.

DW: dry weight, CI: chlorophyll index, NM: non-mycorrhizal, Rc: Rhizophagus clarus , Ri:Rhizophagus intraradices.

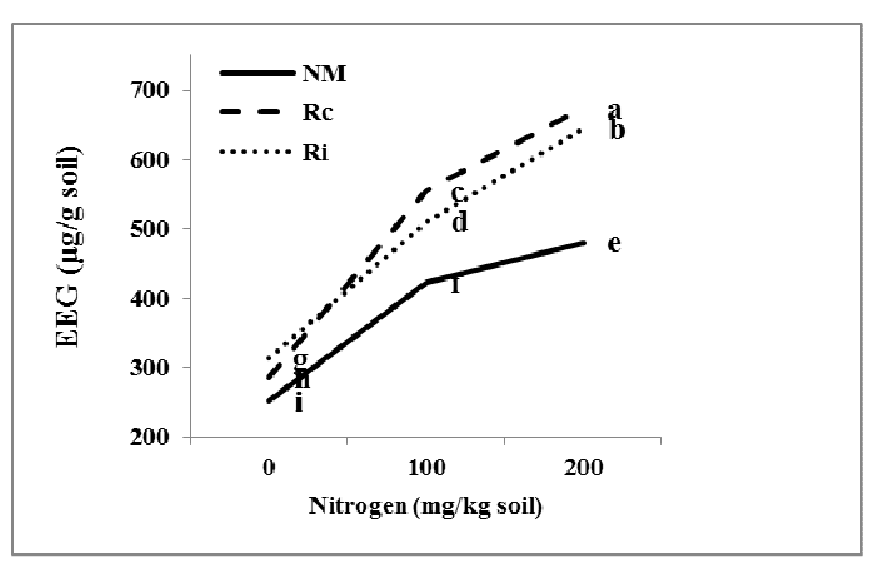

Fig. 1 Effects of nitrogen levels on soil EEG content in mycorrhizal and non-mycorrhizal treatments.

The effect of $\mathrm{P}$ fertilization on EEG production was different from that of $\mathrm{N}$ fertilization. Increasing level of phosphorus fertilizer from P0 to P20 caused a marked enhancement of EEG in both fungi, although the increase was more in Rc than Ri fungus (Fig.2). It seems that P20 level supplies plant with sufficient phosphorus, which in turn carbon allocation to the fungi is enhanced. Under P-limiting conditions the plant will invest in mycorrhizas and/or more roots, simply because it needs to acquire more $P$ [10],[20],[21]. Unlike to the $\mathrm{N}$ fertilizer, increasing of $\mathrm{P}$ to the highest level (40 mg/kg) severely diminished EEG synthesis.

Carbon allocation to the plant may be influenced by phosphorus availability in soil [1]. Higher available P in soil inhibits mycorrhizal fungal development in root and soil, therefore the root pathway for $\mathrm{P}$ uptake dominates mycorrhizal pathway, thus the carbon allocation to the fungus is decreased [11]. Schnepf et al. [19] pointed out that the apparent deactivation of the direct pathway in AM plants might be caused by down regulation of the plant phosphate transporters in root epidermis plus root hairs (directly via the presence of AM fungi or indirectly via increased plant $\mathrm{P}$ status) and/or by competition for $\mathrm{P}$ between roots and hyphae in the depletion cylinder around the root. 


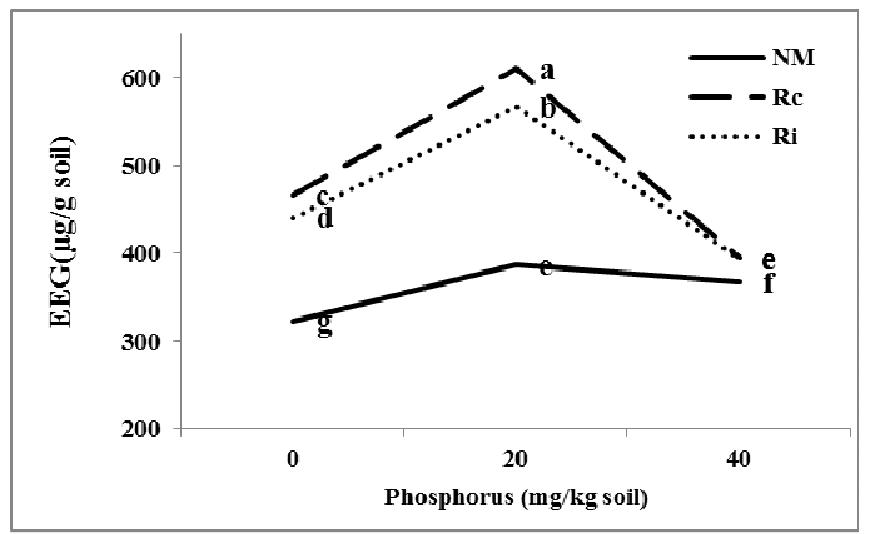

Fig. 2 Effects of phosphorus levels on soil EEG content in mycorrhizal and non-mycorrhizal treatments.

A little increase was seen in non-mycorrhizal treatments as a result of $\mathrm{P}$ fertilization(Fig.2). The likely reason is that higher soluble phosphate in soil at P20 and P40 levels may enhances glomalin extraction with citrate buffer.

\section{SoilTG}

Total glomalin (TG) showed same trend as EEG in response to the $\mathrm{N}$ and $\mathrm{P}$ fertilizations. As described for EEG, the $\mathrm{Rc}$ was also more efficient than $\mathrm{Ri}$ fungus in $\mathrm{TG}$ production (Figs.3\&4). TG is consisted of aged plus newly synthesized glomalin by the fungi.

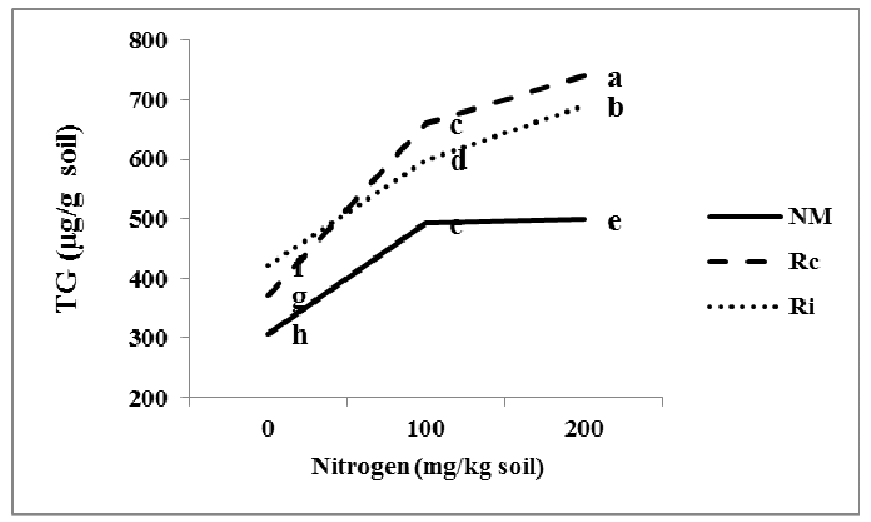

Fig. 3 Effects of nitrogen levels on soil TG content in mycorrhizal and nonmycorrhizal treatments.

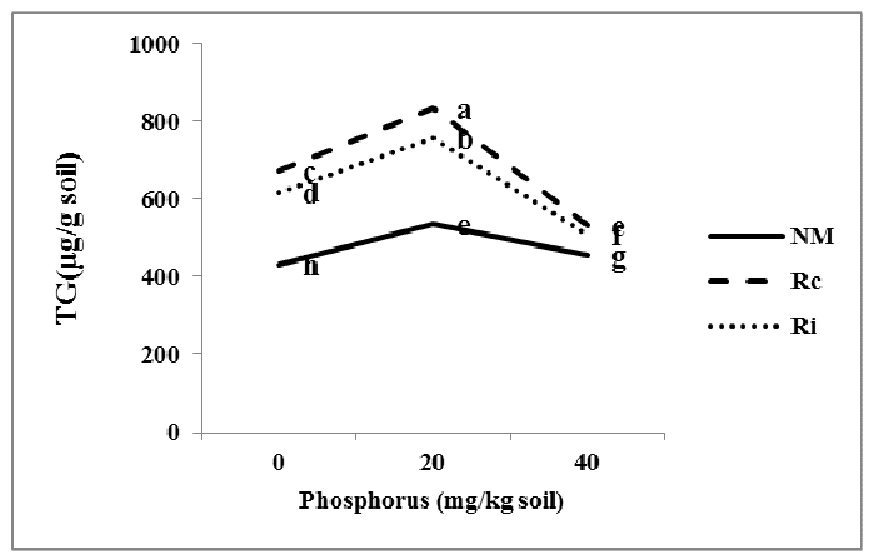

Fig. 4 Effects of phosphorus levels on soil TG content in mycorrhizal and non-mycorrhizal treatments.

\section{Glomalin and Root colonization correlations}

Soil EEG and TG were positively correlated with mycorrhizal root colonization (Figs 5\&6). By increasing root colonization the fungal organs in soil are also proliferated around the root. All AM fungal propagules possess glomalin on their cell walls [16] therefore a marked increase in both glomalin contents was recorded at higher root colonization levels.

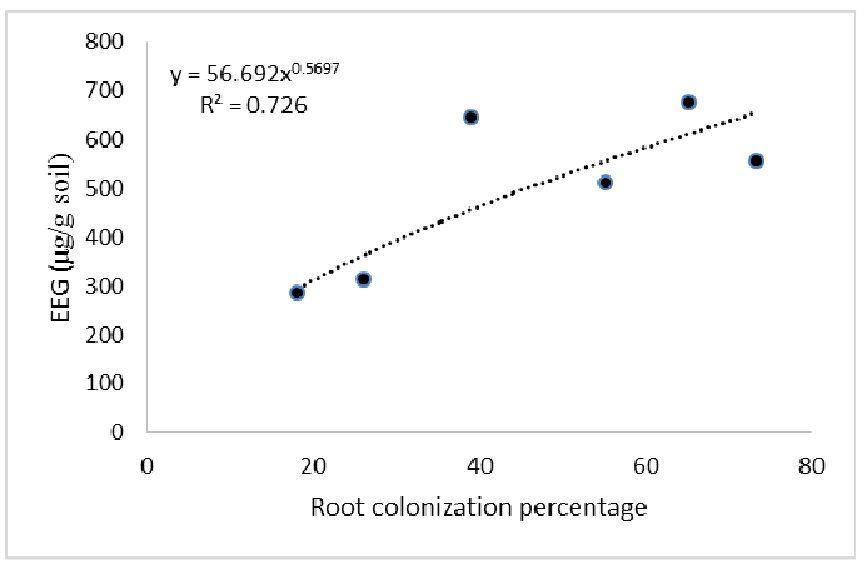

Fig.5 Regression between soil EEG content and mycorrhizal root colonization.

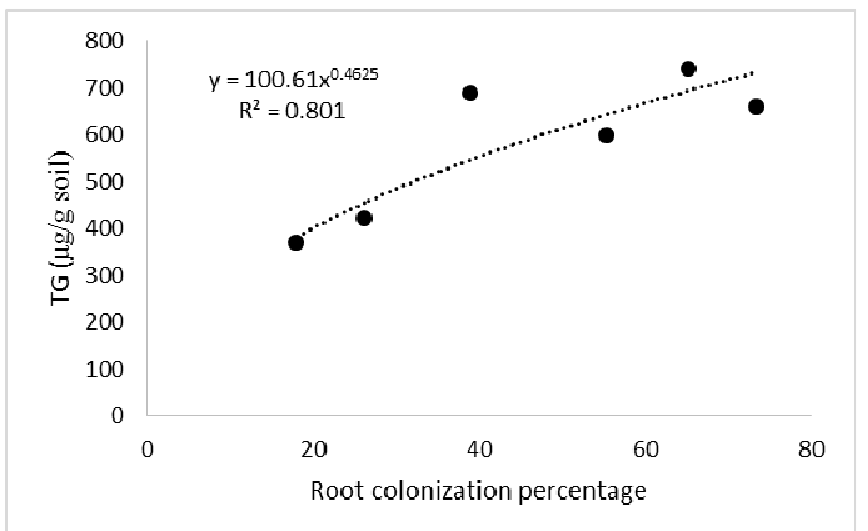

Fig.6 Regression between soil TG content and mycorrhizal root colonization.

\section{CONCLUSIONS}

Carbon sequestration via glomalin synthesis by AM fungi is an important pathway for capturing $\mathrm{CO}_{2}$ from atmosphere. Field managements which help AM development in soil ecosystems, would lead to enhancement of glomalin production [12],[14]. Based on our results, nitrogen fertilizers could positively affect the production of this glycoprotein. Once plant assimilates are translocated to the fungi, they could transform to the nitrogenous compounds if sufficient nitrogen sources are available. By this way, a considerable amount of fixed carbon is assimilated in fungal organs and soil particles as well. Phosphorus application showed some different trend in this respect. By increasing of $\mathrm{P}$ to medium level $\left(20 \mathrm{mg} \mathrm{kg}^{-1}\right)$ a marked increase in glomalin production was seen because of improvement of plant growth. But the enhancement of $\mathrm{P}$ to the higher level (40 $\mathrm{mg} \mathrm{kg} \mathrm{kg}^{-1}$ ) had adverse effect on mycorrhizal root 
colonization and consequently on glomalin production. There are many evidences that sufficient $\mathrm{P}$ supply could diminish carbon allocation to the fungi [1],[11]. It could be concluded that carbon sequestration by arbuscular mycorrhizal symbiosis in terrestrial ecosystems can be improved by $\mathrm{N}$ fertilization at optimum level but $\mathrm{P}$ fertilization at restricted conditions.

\section{ACKNOWLEDGMENT}

Authors wish to thank Prof. Pål Axel Olsson from Biology Department of Lund University, Sweden for providing the fungal species. Financial support by the Research Affairs of the University of Tabriz is gratefully acknowledged.

\section{REFERENCES}

[1] P.A. Olsson, I.M. Van Aarle, M.E. Gavito, P. Bengtson and G. Bengtsson. "13C incorporation into signature fatty acids as an assay for carbon allocation in arbuscular mycorrhiza" Appl Environ Microbiol vol.71, pp.2592-2599, 2005.

[2] D. Johnson, J.R. Leake, N. Ostle, P. Ineson and D.J. Read. "In situ13CO2 pulse-labelling of upland grassland demonstrates a rapid pathway of carbon flux from arbuscular mycorrhizal mycelia to the soil" New Phytol vol.153, pp.327-334, 2002.

[3] M.E. Gavito and P.A. Olsson. "Allocation of plant carbon to foraging and storage in arbuscular mycorrhizal fungi” FEMS Microbiol Ecol vol.45, pp.181-187, 2003.

[4] D.D. Cameron, I. Johnson, D.J. Read and J.R. Leake. "Giving and recieving: measuring the carbon cost of mycorrhizas in the green orchid, Goodyera repens" New Phytol vol.180, pp.176,2008

[5] K.A. Nichols, and S.F. Wright. "Contributions of fungi to soil organic matter in agroecosystems" in Soil Organic Matter in Sustainable Agriculture, F. Magdoff and R.R. Weil Eds., CRC Press, Florida. pp. 179-198, 2004.

[6] S. Purin, and M.C. Rillig. "The arbuscular mycorrhizal fungal protein glomalin: Limitations, progress, and a new hypothesis for its function" Pedobiologia vol.51, pp.123-130, 2007.

[7] V. Gadkar, and M.C. Rillig. "The arbuscular mycorrhizal fungal protein glomalin is a putative homolog of heat shock protein 60 " FEMS Microbiol. Lett. Vol.263, pp.93-101, 2006.

[8] Y. Zhu, and R.M. Miller. "Carbon cycling by arbuscular mycorrhizal fungi in soil-plant systems" Trends Plant Sci. vol.8, pp.407-409, 2003.

[9] P.A. Olsson, J. Rahm and N. Aliasgharzad. "Carbon dynamics in mycorrhizal symbioses is linked to carbon costs and phosphorus benefits" FEMS Microbiol Ecol vol.72, pp.123-131, 2010.

[10] C. F. Landis and L.H. Fraser. "A new model of carbon and phosphorus transfers in arbuscular mycorrhizas". New Phytol vol.177, pp.466-479, 2008.

[11] S.E. Smith, I. Jakobsen, M. Grønlund, and F.A. Smith. "Roles of arbuscular mycorrhizas in plant phosphorus nutrition: Interactions between pathways of phosphorus uptake in arbuscular mycorrhizal roots have important implications for understanding and manipulating plant phosphorus acquisition" Plant Physiol. vol.156, pp.1050-1057, 2011.

[12] M.C. Rillig, P.W. Ramsey, S. Morris and E.A. Paul. "Glomalin, an arbuscular-mycorrhizal fungal soil protein, responds to land-use change" Plant Soil vol.253, pp.293-299, 2003a.

[13] M.C. Rillig, and P.D. Steinberg. "Glomalin production by an arbuscular mycorrhizal fungus: a mechanism of habitat modification" Soil Biol Biochem vol.34, pp.1371-1374, 2002.

[14] S.F. Wright and A. Upadhyaya. "A survey of soils for aggregate stability and glomalin, a glycoprotein produced by hyphae of arbuscular mycorrhizal fungi" Plant and Soil vol.198, pp.97107,1998 .

[15] N. Aliasgharzadeh, N. Saleh Rastin, H. Towfighi and A. Alizadeh. "Occurrence of arbuscular mycorrhizal fungi in saline soils of the Tabriz Plain of Iran in relation to some physical and chemical properties of soil" Mycorrhiza vol.11, pp.119-122, 2001.

[16] S.F. Wright, M. Franke-Snyder, J.B. Morton and A. Upadhyaya. "Time-course study and partial characterization of a protein on hyphae of arbuscular mycorrhizal fungi during active colonization of roots" Plant and Soil vol.181, pp.193-203, 1996.

[17] J.D. Driver, W.E. Holben and M.C. Rillig. "Characterization of glomalin as a hyphal wall component of arbuscular mycorrhizal fungi" Soil Biol Biochem vol.37, pp.101-106, 2005.

[18] K.K. Treseder, and K.M. Turner. "Glomalin in ecosystems" Soil Sci. Soc. Am. J. vol.71, pp.1257-1266, 2007.

[19] A. Schnepf, T. Roose, P. Schweiger. "Impact of growth and uptake patterns of arbuscular mycorrhizal fungi on plant phosphorus uptake: a modelling study" Plant Soil vol.312, pp.85-99, 2008.

[20] I. Jakobsen. "Transport of phosphorus and carbon in arbuscular mycorrhizas" in Mycorrhiza: Structure, Function, Molecular Biology and Biotechnology A. Varma and B. Hock, Eds, Edition 2. Springer, Berlin, pp 309-332, 1999.

[21] A.H. Fitter. "What is the link between carbon and phosphorus fluxes in arbuscular mycorrhizas? A null hypothesis for symbiotic function" New Phytol. vol.172, pp.3-6, 2006.

[22] O.M. Garcia, T. Ovasapyan, M. Greas K.K. Treseder. "Mycorrhizal dynamics under elevated $\mathrm{CO} 2$ and nitrogen fertilization in a warm temperate forest" Plant Soil vol.303, pp.301-310, 2008.

[23] P.P. Kormanik, A.C. McGraw. "Quantification of vesiculararbuscular mycorrhizae in plant roots" in Methods and Principles of Mycorrhizal Research N.C. Schenck, Ed. The American Phytopathological Society, St. Paul, pp.37-45, 1982.

[24] Q.S. Wu, X.H. He, Y.N. Zou, K.P. He, Y.H. Sun and M.Q. Cao "Spatial distribution of glomalin-related soil protein and its relationships with root mycorrhization, soil aggregates, carbohydrates, activity of protease and $\beta$-glucosidase in the rhizosphere of Citrus unshiu" Soil Biol. Biochem. Vol.45, pp.181183, 2012.

[25] M. Giovanetti and B. Mosse. "An evaluation of techniques for measuring vesicular-arbuscular infections in roots" New Phytol. vol.84, pp.489-500, 1980.

[26] M.M. Bradford. "A rapid and sensitive method for the quantitation of microgram quantities of protein utilizing the principle of protein-dye binding" Analytical Biochem. vol.72, pp. 248-254, 1976. 